\title{
Public Health Policies on E-Cigarettes
}

\section{Aditya Bhalerao $^{1}$ - Farzane Sivandzade ${ }^{1}$ - Sabrina Rahman Archie ${ }^{1}$. Luca Cucullo ${ }^{1,2}$}

Published online: 28 August 2019

(C) The Author(s) 2019

\begin{abstract}
Tobacco continues to kill about 0.48 million Americans per year and there are currently 34.3 million smokers in the USA. As a consequence of the First Surgeon General's Report on Tobacco in 1964, tobacco control interventions on part of the government led to a significant decline in conventional tobacco product usage over the last few decades. However, more recently, a new entity in the form of electronic cigarettes has risen rapidly and has exposed a younger population to a plethora of dangerous consequences. Looking at e-cigarettes from the perspective of tobacco control however raises a lot of challenges. There is little doubt that existing smokers of combustible cigarettes who switch to e-cigarettes will be switching to a less harmful product. However, if the younger generation begins using e-cigarettes as a result of targeted marketing, appealing flavors and 'safer alternative' perception, decades of progress made in conventional tobacco control will be negated. Governments at the federal, state, and local levels have a mandate to once again implement new public health policies to ensure that non-conventional tobacco products like e-cigarettes are available as smoking cessation tools for existing smokers but at the same time do not play a role in ruining the health of future generations through addiction and disease.

Purpose of Review To review the present scenario of regulations and policies impacting public health with respect to electronic nicotine delivery systems (ENDS) with the objective of providing a meaningful and balanced view of the challenges at hand with plausible recommendations.

Recent Findings Nicotine in tobacco is known to cause addiction and dependence. It is particularly potent in children and young adults. E-cigarettes can deliver high concentrations of nicotine, and these concentrations can vary depending on the numerous constituents within the e-cigarette which vary greatly from one another. Use of e-cigarettes is implicated as a risk factor for future cigarette use in young adults. Moreover, e-cigarette usage patterns also depend on several sociodemographic factors. Banning tobacco products has shown to reduce smoking risk in youth and as such, strong e-cigarette regulation measures are needed for prevention. Summary Effective regulation of ENDS faces a multitude of challenges. One such challenge is to prevent youth and nonsmokers from getting habituated to nicotine through e-cigarettes. The intention of tobacco companies to sustain sales through harmful marketing strategies that tone down the risks and highlight e-cigarettes as a "much safer alternative" while promoting flavors appealing to children should be immediately prohibited. Another hazard is the endorsement of ENDS as devices meant for enhancing social interaction which opens a path for youth to make erroneous choices under peer pressure. On the other hand, several studies have reported that e-cigarettes significantly reduce an existing smoker's risk of being exposed to toxic tobacco smoke constituents that are normally present in cigarette smoke. This leads to the conclusions that e-cigarettes can be a tool for smoking cessation for current smokers. Public policy must take a multi-dimensional approach to balance these two extremes.
\end{abstract}

Keywords E-cigarettes $\cdot$ Electronic cigarettes $\cdot$ Electronic nicotine delivery systems $\cdot$ Policy $\cdot$ Regulation $\cdot$ Public health

This article is part of the Topical Collection on Public Health Policy

Luca Cucullo

luca.cucullo@ttuhsc.edu

Aditya Bhalerao

aditya.bhalerao@ttuhsc.edu

Farzane Sivandzade

farzane.sivandzade@ttuhsc.edu
Sabrina Rahman Archie

Sabrina.Archie@ttuhsc.edu

1 Department of Pharmaceutical Sciences, Jerry H. Hodge School of Pharmacy, Texas Tech University Health Sciences Center, $1300 \mathrm{~S}$. Coulter Street, Amarillo, TX 79106, USA

2 Center for Blood Brain Barrier Research, TTUHSC, Amarillo, TX 79106, USA 


\section{Introduction}

Electronic nicotine delivery systems (ENDS) are commonly known as electronic cigarettes or e-cigarettes and vape pens. These devices are meant to deliver nicotine by heating up a vape liquid into an inhalable aerosol. The vape liquid is a solution containing nicotine, flavoring agents, and solvents such as propylene glycol or glycerin [1]. The e-cigarette was first invented by Herbert A Gilbert in 1963, but the subsequent commercially viable design was patented by Hon Lik of China [2]. E-cigarettes entered the US market in 2007 [3] and have gained tremendous popularity since, especially among youth. Ecigarettes were marketed as a safer alternative to conventional combustible cigarettes and therefore were promoted as harm reduction substitutes for current smokers. However, there are contrasting claims associated with ecigarettes being considered as a safer alternative to conventional cigarettes. The bottom-line according to the Centers for Disease Control and Prevention remains that e-cigarettes are possibly a less harmful alternative for current smokers addicted to combustible cigarettes [4.•]. Ecigarettes are not for people who have never smoked in their life, and even establishing their efficacy as a smoking cessation tool needs thorough and long-term research [5]. The dangers of e-cigarette vaping include damage to the developing brain from nicotine [6-8] and exposure to toxic substances such as heavy metals, volatile organic compounds, and ultrafine particles $[9,10 \bullet]$.

\section{Public Health Consequences}

The adverse health consequences of e-cigarette use for both primary smokers and those exposed to secondhand smoke arises from the inhalation of the e-cigarette aerosol and levels of nicotine delivered into the system [11, 12].

Nicotine is known to be acutely toxic at high doses, and cases of nicotine poisonings due to vape liquids have seen a rise in recent years [13]. Nicotine is also a pharmacologically active biomolecule that sustains addiction, changes the way one's brain functions [14], and is known to have particularly harmful consequences on the growing fetus if exposed to it during pregnancy $[15,16]$.

The e-cigarette aerosol contains a vast array of chemicals including any number of approximately 7000 flavorings [17], humectants such as Propylene Glycol and Vegetable Glycerin and contaminants such as metals, formaldehyde, acrolein, and tobacco-specific nitrosamines $[1,18]$ all with the potential to cause a wide variety of negative health effects. A list of these compounds and their physiologic effects are outlined below (Table 1).
Need for Regulation

In the years before the advent of ENDS technology, various public health measures made significant progress in tobacco control yielding a $6.9 \%$ reduction in smoking across the US population from 2005 to 2017 [32-35]. Keeping in mind the economic and social burden exacted by smoking-related diseases, the Federal Government had enacted various laws to make the sale of conventional tobacco products more difficult especially for the younger generation. However, rapid and unchecked increase in ecigarette use $\left[10^{\bullet}, 36\right]$ has once again threatened to endanger the health of our youth through nicotine addiction and vaping related disease $[6,37]$. The National Youth Tobacco Survey held jointly by the FDA and the Centers for Disease Control and Prevention shows that around 3.6 million students (both middle and high school) were using e-cigarettes in 2018, up from 2.1 million in 2017 [38, 39]. There is emerging evidence that ecigarettes can spur future tobacco product use in teens, whereas, on the other hand, banning tobacco products diminishes the smoking risk. Socio-economic background is another factor that also plays a major role in smoking initiation [40-42].

Another area of concern is the public health consequences of secondhand e-cigarette smoke on bystanders. Though the country has made significant progress in enacting clean air laws in public places including workplaces and indoors, a lot still remains to be done. The use of e-cigarettes in public areas poses a serious health risk considering the various toxic constituents that have been shown to affect both the primary smoker and victims of passive smoking. It is pertinent to note that smoke-free laws in the USA were passed before ENDS entered the market and do not specifically mention the prohibition of e-cigarette smoking in many places. As such, this non-clarity may lead to non-compliance or exploitation of smoke-free rules [43, 44].

\section{Existing Regulation}

\section{Federal Regulations}

The FDA has been regulating tobacco products since June 2009; a timeline of the most important regulations is furnished in Table 2.

On May 10, 2016, the U.S. Food and Drug Administration (FDA) passed a new rule effective August 08, 2016, deeming that all tobacco products be brought under the purview of Federal Food, Drug, and Cosmetic Act thus authorizing the FDA to regulate all tobacco products including ENDS [46]. Apart from banning the sale of e-cigarettes to those below 18 years of age, the rule also stipulates several manufacturing 
Table 1 Constituents of ENDS Aerosol [19]

\begin{tabular}{|c|c|c|c|}
\hline $\begin{array}{l}\text { Serial } \\
\text { number }\end{array}$ & Aerosol component & Health risk & Reference \\
\hline 1. & Ultrafine particles & Asthma, vasoconstriction leading to cardiovascular problems & {$[20,21]$} \\
\hline 2. & $\begin{array}{l}\text { Benzene, formaldehyde, acetaldehyde, } \\
\text { toluene, cadmium, lead, and nickel }\end{array}$ & Carcinogen, reproductive toxin & {$[22,23]$} \\
\hline 3. & Propylene glycol & Irritant of the eyes, throat and airways, long-term exposure leads to asthma & {$[24,25]$} \\
\hline 4. & Propylene oxide & Carcinogen & {$[26]$} \\
\hline 5. & Diethylene glycol & renal and neurologic toxicity & {$[27]$} \\
\hline 6. & Diacetyl and acetyl propionyl (sweet flavorings) & bronchiolitis obliterans & {$[28,29]$} \\
\hline 7. & Carbonyls & Cardiovascular toxicity & {$[30]$} \\
\hline 8. & Copper nanoparticles & DNA fragmentation, mitochondrial stress & [31] \\
\hline
\end{tabular}

standards and marketing limitations. The rule focuses on preventing a younger generation from becoming addicted to nicotine through e-cigarettes while taking into account the harm reduction potential of e-cigarettes for existing smokers addicted to nicotine.

More recently, in light of the 2018 National Youth Tobacco Survey, the FDA and Federal Trade Commission (FTC) issued warnings to four e-cigarette manufacturing companies around youth-focused advertisement, sale and distribution of ENDS products, especially on social media platforms [47].

\section{State Regulations of e-Cigarettes}

The US state and local governments have played a proactive role in enacting several laws at their level to protect against the misuse of e-cigarettes. In June 2019, San Francisco, California, became the first city in the USA to ban the retail and online sale of e-cigarettes. This move is especially significant as Juul Labs, Inc., the makers of the Juul e-cigarettes variety, which has captured $70 \%$ of ENDS market share in recent years, is based out of San Francisco. Another trend is the implementation of Tobacco 21 laws in several states, increasing the minimum age of sale of tobacco products from 18 to 21. As of June 2019, 16 states, Arkansas, California,
Connecticut, Delaware, Hawaii, Illinois, Maine, Maryland, Massachusetts, New Jersey, Oregon, Texas, Utah, Vermont, Virginia, and Washington, the District of Columbia and 470 localities had implemented tobacco 21 laws [48].

As of April 2019, 13 states, 2 territories, and 841 municipalities have banned the use of e-cigarettes in $100 \%$ smokefree public places [43]. In addition, regulations defining ecigarettes, taxation, packaging, access to youth, and licensure of e-cigarette sales have been put into place across several states (Table 3).

\section{Challenges and Recommendations}

A review of the scientific literature shows largely incomplete data around the health effects of e-cigarettes. This translates to policy indecision among the regulatory authorities leading to confusion among the general public. This also causes problems for health care professionals in counseling current smokers looking to switch to e-cigarettes [50-52]. A longterm comprehensive study involving all major stakeholders is required to address this problem.

A bi-pronged approach could be key in balancing the regulatory aspects of e-cigarettes. It should consist of a

Table 2 Timeline of policies/rules/regulations enforced at the federal level

\begin{tabular}{|c|c|c|c|c|}
\hline No. & Date & Name of agency & Regulation particulars & Implication \\
\hline 1. & June, 2009 & $\begin{array}{l}\text { Food and Drug Administration (FDA) } \\
\text { of the Department of Health and } \\
\text { Human Services. }\end{array}$ & $\begin{array}{l}\text { Family Smoking Prevention and } \\
\text { Tobacco Control Act. [45] }\end{array}$ & $\begin{array}{l}\text { Authorizing FDA to regulate } \\
\text { tobacco products including e-cigarettes. } \\
\text { It led to the creation } \\
\text { of center for tobacco products. }\end{array}$ \\
\hline 2. & April, 2014 & $\begin{array}{l}\text { Food and Drug Administration (FDA) } \\
\text { of the Department of Health and } \\
\text { Human Services. }\end{array}$ & Proposed Deeming Regulations [46] & $\begin{array}{l}\text { Authorized the FDA to put heavy } \\
\text { restrictions on most of the existing } \\
\text { unregulated e-cigarette } \\
\text { manufacturing industry } \\
\text { and required premarket } \\
\text { tobacco applications (PMTA's) } \\
\text { for new manufacturers }\end{array}$ \\
\hline
\end{tabular}


Table 3 Law(s) in effect across all States \& the District of Columbia in the USA (March 15, 2019) [49]

\begin{tabular}{|c|c|c|c|c|c|c|}
\hline & State & $\begin{array}{l}\text { Law(s) that define } \\
\text { e-cigarettes }\end{array}$ & $\begin{array}{l}\text { Law(s) taxing } \\
\text { e-cigarettes }\end{array}$ & $\begin{array}{l}\text { Law(s) on product } \\
\text { packaging of e-cigarettes }\end{array}$ & $\begin{array}{l}\text { Law(s) restricting youth } \\
\text { access to e-cigarettes }\end{array}$ & $\begin{array}{l}\text { Law(s) requiring licenses for } \\
\text { retail sales of e-cigarettes }\end{array}$ \\
\hline 1 & Alabama & & & & Yes & \\
\hline 2 & Alaska & & & & Yes & Yes \\
\hline 3 & Arizona & & & & Yes & \\
\hline 4 & Arkansas & & & Yes & Yes & Yes \\
\hline 5 & California & Yes & Yes & Yes & Yes & Yes \\
\hline 6 & Colorado & Yes & & & Yes & \\
\hline 7 & Connecticut & & & & Yes & Yes \\
\hline 8 & Delaware & Yes & Yes & & Yes & Yes (vape liquid) \\
\hline 9 & $\begin{array}{l}\text { District of } \\
\text { Columbia }\end{array}$ & Yes & Yes & & Yes & Yes \\
\hline 10 & Florida & & & & Yes & \\
\hline 11 & Georgia & & & & Yes & \\
\hline 12 & Hawaii & Yes & & & Yes & Yes \\
\hline 13 & Idaho & & & & Yes & \\
\hline 14 & Illinois & & & Yes & Yes & \\
\hline 15 & Indiana & Yes & & Yes & Yes & Yes \\
\hline 16 & Iowa & & & & Yes & Yes \\
\hline 17 & Kansas & & Yes & & Yes & Yes \\
\hline 18 & Kentucky & & & & Yes & \\
\hline 19 & Louisiana & & Yes & & Yes & Yes \\
\hline 20 & Maine & Yes & & Yes & Yes & Yes \\
\hline 21 & Maryland & & & & Yes & Yes \\
\hline 22 & Massachusetts & Yes & & Yes & Yes & \\
\hline 23 & Michigan & & & & & \\
\hline 24 & Minnesota & Yes & Yes & Yes & Yes & Yes \\
\hline 25 & Mississippi & & & & Yes & \\
\hline 26 & Missouri & & & Yes & Yes & Yes \\
\hline 27 & Montana & & & & Yes & Yes \\
\hline 28 & Nebraska & & & & Yes & \\
\hline 29 & Nevada & & & & Yes & \\
\hline 30 & $\begin{array}{l}\text { New } \\
\text { Hampshire }\end{array}$ & & & Yes & Yes & \\
\hline 31 & New Jersey & Yes & Yes & Yes & Yes & \\
\hline 32 & New Mexico & & & Yes & Yes & \\
\hline 33 & New York & & & Yes & Yes & \\
\hline 34 & $\begin{array}{l}\text { North } \\
\quad \text { Carolina }\end{array}$ & Yes & Yes & Yes & Yes & Yes (non-local manufacturers) \\
\hline 35 & North Dakota & & & Yes & Yes & \\
\hline 36 & Ohio & & & Yes & Yes & \\
\hline 37 & Oklahoma & & & & Yes & \\
\hline 38 & Oregon & & & Yes & Yes & \\
\hline 39 & Pennsylvania & Yes & Yes & Yes & & Yes \\
\hline 40 & Rhode Island & & & Yes & Yes & Yes \\
\hline 41 & $\begin{array}{l}\text { South } \\
\quad \text { Carolina }\end{array}$ & & & & Yes & \\
\hline 42 & South Dakota & Yes & & Yes & Yes & \\
\hline 43 & Tennessee & & & Yes & Yes & \\
\hline 44 & Texas & & & Yes & Yes & Yes \\
\hline 45 & Utah & Yes & & Yes & Yes & Yes \\
\hline 46 & Vermont & & & Yes & Yes & Yes \\
\hline 47 & Virginia & & & Yes & Yes & \\
\hline 48 & Washington & & & Yes & Yes & Yes \\
\hline 49 & West Virginia & Yes & Yes & & Yes & \\
\hline 50 & Wisconsin & & & & Yes & \\
\hline 51 & Wyoming & Yes & & Yes & Yes & \\
\hline
\end{tabular}

prevention strategy in case of youth and a control strategy for current smokers who are looking at reduced harm alternatives for their nicotine fixation [53]. The prevention aspect can include laws that prohibit sale to minors, prevent youth-targeted advertisement campaigns [54, 55] and flavors, child-safe packaging, and campaigns addressing awareness and education. On the other hand, the control aspect can include better manufacturing measures, licensing laws for retail and online sale, selective taxation, and supervised subsidy for verified current smokers. 


\section{Conclusions}

Every once in a while, a newer technology emerges onto the market and causes a massive shift in the prevailing status quo. E-cigarettes are one such technology that emerged a decade ago and has changed the way tobacco is consumed by the current population. It has brought along with it many dangers but also some promises. The regulatory framework has to tread a narrow path of prevention and control to safeguard future generation against the evils of tobacco as well as other unintended health consequences of using ENDS, but at the same time ensure that the path from combustible cigarettes to e-cigarettes ends with complete smoking cessation.

Author Contributions A.B. conceived the study and prepared the drafting of the manuscript. F.S. and S.R.A. also contributed to the manuscript preparation. L.C. assisted with the drafting of the manuscript, oversaw the entire project, and provided funding support. All authors reviewed the manuscript.

Funding Information This work was supported by the National Institutes of Health/National Institute on Drug Abuse 2R01-DA029121-01A1 and ARDF to Dr. Luca Cucullo.

\section{Compliance with Ethical Standards}

Conflict of Interest Aditya Bhalerao, Farzane Sivandzade, Sabrina Rahman Archie, and Luca Cucullo declare that they have no conflict of interest.

Human and Animal Rights and Informed Consent This article does not contain any studies with human or animal subjects performed by any of the authors.

Open Access This article is distributed under the terms of the Creative Commons Attribution 4.0 International License (http:// creativecommons.org/licenses/by/4.0/), which permits unrestricted use, distribution, and reproduction in any medium, provided you give appropriate credit to the original author(s) and the source, provide a link to the Creative Commons license, and indicate if changes were made.

\section{References}

Papers of particular interest, published recently, have been highlighted as:

- Of importance

•. Of major importance

1. Clapp PW, Jaspers I, Cigarettes E. Their constituents and potential links to asthma. Curr Allergy Asthma Rep. 2017;17(11):79.

2. Bhatnagar A, Whitsel LP, Ribisl KM, Bullen C, Chaloupka F, Piano $\mathrm{MR}$, et al. Electronic cigarettes: a policy statement from the American Heart Association. Circulation. 2014;130(16):1418-36.

3. Lichtenberg K. E-cigarettes: current evidence and policy. Mo Med. 2017;114(5):335-8.
4.• Huang J, et al. Changing perceptions of harm of e-cigarette vs cigarette use among adults in 2 US national surveys from 2012 to 2017. JAMA Netw Open. 2019;2(3):e191047. The authors of this study observed that a huge proportion of adults in the US perceived e-cigarettes as equally or more harmful than conventional cigarettes.

5. [CDC], T.C.f.D.C.a.P. Smoking \& tobacco use about electronic cigarettes (e-cigarettes) quick facts on the risks of e-cigarettes for kids, teens, and young adults. https://www.cdc.gov/tobacco/basic information/e-cigarettes/about-e-cigarettes.html, 2019.

6. DeVito EE, Krishnan-Sarin S. E-cigarettes: impact of E-liquid components and device characteristics on nicotine exposure. Curr Neuropharmacol. 2018;16(4):438-59.

7. Siqueira LM. Nicotine and tobacco as substances of abuse in children and adolescents. Pediatrics. 2017;139(1):e20163436.

8. Glasser AM, Collins L, Pearson JL, Abudayyeh H, Niaura RS, Abrams DB, et al. Overview of electronic nicotine delivery systems: a systematic review. Am J Prev Med. 2017;52(2):e33-66.

9. Collaco JM, Drummond MB, McGrath-Morrow SA. Electronic cigarette use and exposure in the pediatric population. JAMA Pediatr. 2015;169(2):177-82.

10. Jenssen BP, Boykan R. Electronic cigarettes and youth in the United States: a call to action (at the Local, National and Global Levels). Children (Basel). 2019;6(2). The authors of this review suggest that there is an increasing popularity of ENDS that may reverse years of progress made in tobacco control.

11. Czogala J, Goniewicz ML, Fidelus B, Zielinska-Danch W, Travers MJ, Sobczak A. Secondhand exposure to vapors from electronic cigarettes. Nicotine Tob Res. 2014;16(6):655-62.

12. Cai H, Wang C. Graphical review: the redox dark side of ecigarettes; exposure to oxidants and public health concerns. Redox Biol. 2017;13:402-6.

13. Kim JW, Baum CR. Liquid nicotine toxicity. Pediatr Emerg Care. 2015;31(7):517-21 quiz 522-4

14. Yuan M, Cross SJ, Loughlin SE, Leslie FM. Nicotine and the adolescent brain. J Physiol. 2015;593(16):3397-412.

15. Spindel ER, McEvoy CT. The role of nicotine in the effects of maternal smoking during pregnancy on lung development and childhood respiratory disease. Implications for dangers of E-cigarettes. Am J Respir Crit Care Med. 2016;193(5):486-94.

16. Hagino N, Lee JW. Effect of maternal nicotine on the development of sites for $[(3) \mathrm{H}]$ nicotine binding in the fetal brain. Int J Dev Neurosci. 1985;3(5):567-71.

17. Zhu SH, Sun JY, Bonnevie E, Cummins SE, Gamst A, Yin L, et al. Four hundred and sixty brands of e-cigarettes and counting: implications for product regulation. Tob Control. 2014;23(Suppl 3):iii39.

18. Margham J, McAdam K, Forster M, Liu C, Wright C, Mariner D, et al. Chemical composition of aerosol from an E-cigarette: a quantitative comparison with cigarette smoke. Chem Res Toxicol. 2016;29(10):1662-78.

19. Foundation, A.N.R. Electronic smoking devices and secondhand aerosol. Website, 2019. https://no-smoke.org/electronic-smokingdevices-secondhand-aerosol/.

20. Fuoco FC, Buonanno G, Stabile L, Vigo P. Influential parameters on particle concentration and size distribution in the mainstream of e-cigarettes. Environ Pollut. 2014;184:523-9.

21. Grana R, Benowitz N, Glantz SA. Background paper on Ecigarettes (electronic nicotine delivery systems). Center for Tobacco Control Research and Education University of California, San Francisco WHO Collaborating Center on Tobacco Control, 2013.

22. Goniewicz ML, Knysak J, Gawron M, Kosmider L, Sobczak A, Kurek J, et al. Levels of selected carcinogens and toxicants in vapour from electronic cigarettes. Tob Control. 2014;23(2):133-9. 
23. Williams M, Villarreal A, Bozhilov K, Lin S, Talbot P. Metal and silicate particles including nanoparticles are present in electronic cigarette cartomizer fluid and aerosol. PLoS One. 2013;8(3): e57987.

24. Wieslander G, Norback D, Lindgren T. Experimental exposure to propylene glycol mist in aviation emergency training: acute ocular and respiratory effects. Occup Environ Med. 2001;58(10):649-55.

25. Choi H, Schmidbauer N, Spengler J, Bornehag CG. Sources of propylene glycol and glycol ethers in air at home. Int J Environ Res Public Health. 2010;7(12):4213-37.

26. Program NT. 14th report on carcinogens. Washington, D.C.: U.S. Department of Health and Human Services; 2016.

27. Schep LJ, Slaughter RJ, Temple WA, Beasley DMG. Diethylene glycol poisoning. Clin Toxicol (Phila). 2009;47(6):525-35.

28. Farsalinos KE, Kistler KA, Gillman G, Voudris V. Evaluation of electronic cigarette liquids and aerosol for the presence of selected inhalation toxins. Nicotine Tob Res. 2015;17(2):168-74.

29. (NIOSH), N.I.f.O.S.a.H. Preventing lung disease in workers who use or make flavorings. Atlanta: Centers for Disease Control and Prevention; 2003.

30. Bhatnagar A. E-cigarettes and cardiovascular disease risk: evaluation of evidence, policy implications, and recommendations. Curr Cardiovasc Risk Rep. 2016;10(24). https://doi.org/10.1007/ s12170-016-0505-6.

31. Lerner CA, Rutagarama P, Ahmad T, Sundar IK, Elder A, Rahman I. Electronic cigarette aerosols and copper nanoparticles induce mitochondrial stress and promote DNA fragmentation in lung fibroblasts. Biochem Biophys Res Commun. 2016;477(4):620-5.

32. Cummings KM, Proctor RN. The changing public image of smoking in the United States: 1964-2014. Cancer Epidemiol Biomark Prev. 2014;23(1):32-6.

33. Prevention, C.f.D.C.a. Current cigarette smoking among adults in the United States. Smoking \& tobacco use, 2017. https://www.cdc. gov/tobacco/data_statistics/fact_sheets/adult_data/cig_smoking/ index.htm.

34. National Center for Chronic Disease, P., S. Health Promotion Office on, and Health. Reports of the surgeon general. In: The health consequences of smoking- 50 years of progress: a report of the surgeon general. Centers for Disease Control and Prevention (US): Atlanta; 2014

35. Wang TW, Asman K, Gentzke AS, Cullen KA, Holder-Hayes E, Reyes-Guzman C, et al. Tobacco product use among adults - United States, 2017. MMWR Morb Mortal Wkly Rep. 2018;67(44):122532 .

36. Jenssen BP, Walley SC, McGrath-Morrow SA. Heat-not-burn tobacco products: tobacco industry claims no substitute for science. Pediatrics. 2018;141(1):e20172383.

37. Nasr SZ, Nasrallah AI, Abdulghani M, Sweet SC. The impact of conventional and nonconventional inhalants on children and adolescents. Pediatr Pulmonol. 2018;53(4):391-9.

38. Gentzke AS, Creamer ML, Cullen KA, Ambrose BK, Willis G, Jamal A, et al. Vital signs: tobacco product use among middle and high school students - United States, 2011-2018. MMWR Morb Mortal Wkly Rep. 2019;68(6):157-64.

39. Wang TW, Gentzke A, Sharapova S, Cullen KA, Ambrose BK, Jamal A. Tobacco product use among middle and high school students - United States, 2011-2017. MMWR Morb Mortal Wkly Rep. 2018;67(22):629-33.

40. Soneji S, Barrington-Trimis JL, Wills TA, Leventhal AM, Unger $\mathrm{JB}$, Gibson LA, et al. Association between initial use of e-cigarettes and subsequent cigarette smoking among adolescents and young adults: a systematic review and meta-analysis. JAMA Pediatr. 2017;171(8):788-97.

41. Hartwell G, Thomas S, Egan M, Gilmore A, Petticrew M. Ecigarettes and equity: a systematic review of differences in awareness and use between sociodemographic groups. Tob Control. 2017;26(e2):e85-91.

42. Nuyts PAW, Kuijpers TG, Willemsen MC, Kunst AE. How can a ban on tobacco sales to minors be effective in changing smoking behaviour among youth? - a realist review. Prev Med. 2018;115: 61-7.

43. Foundation, A.N.R., Electronic smoking devices (ESDs). Website, 2019. https://no-smoke.org/smokefree-threats/electroniccigarettes/.

44. Foundation, A.N.R. Electronic smoking devices (ESDs) \& smokefree laws. Website, 2019. https://no-smoke.org/wp-content/ uploads/pdf/e-cigarette-4-pager.pdf.

45. America, G.o.U.S.o. Family smoking prevention and tobacco control act. 2009.

46. U.S. Food and Drug Administration (FDA), H. Deeming tobacco products to be subject to the federal food, drug, and cosmetic act, as amended by the family smoking prevention and tobacco control act; restrictions on the sale and distribution of tobacco products and required warning statements for tobacco products. Final rule. Fed Regist. 2016;81(90):28973-9106.

47. U.S. Food and Drug Administration (FDA), H. FDA, FTC take action to protect kids by citing four firms that make, sell flavored e-liquids for violations related to online posts by social media influencers on their behalf. 2019 [cited 2019 06/27/2019].

48. Kids, C.f.T.-F. U.S. State and local issues raising the tobacco age to 21. 2019 [cited 2019 06/28/2019].

49. Law, P.H.L.C.a.M.H.S.o. U.S. E-cigarette regulations - 50 state review (2019). 2019 [cited 2019].

50. Levy DT, Cummings KM, Villanti AC, Niaura R, Abrams DB, Fong GT, et al. A framework for evaluating the public health impact of e-cigarettes and other vaporized nicotine products. Addiction. 2017;112(1):8-17.

51. El Dib R, et al. Electronic nicotine delivery systems and/or electronic non-nicotine delivery systems for tobacco smoking cessation or reduction: a systematic review and meta-analysis. BMJ Open. 2017;7(2):e012680.

52. Drope J, Cahn Z, Kennedy R, Liber AC, Stoklosa M, Henson R, et al. Key issues surrounding the health impacts of electronic nicotine delivery systems (ENDS) and other sources of nicotine. CA Cancer J Clin. 2017;67(6):449-71.

53. Polosa R, Russell C, Nitzkin J, Farsalinos KE. A critique of the US surgeon general's conclusions regarding e-cigarette use among youth and young adults in the United States of America. Harm Reduct J. 2017;14(1):61.

54. Kaur J, Rinkoo AV. Getting real with the upcoming challenge of electronic nicotine delivery systems: the way forward for the SouthEast Asia region. Indian J Public Health. 2017;61(Suppl 1):S7-s11.

55. Stone $\mathrm{E}$, Marshall $\mathrm{H}$. Tobacco and electronic nicotine delivery systems regulation. Transl Lung Cancer Res. 2019;8(Suppl 1):S67s76.

Publisher's Note Springer Nature remains neutral with regard to jurisdictional claims in published maps and institutional affiliations. 